\title{
Impact of corporate social responsibility toward employees on business performance: The case
} of Vietnam

\author{
Thi Minh Phuong Nguyen ${ }^{a}$, Quang Bach Tran ${ }^{a}$, Duc Tai Do ${ }^{b^{*}}$ and Dieu Linh Trana
}

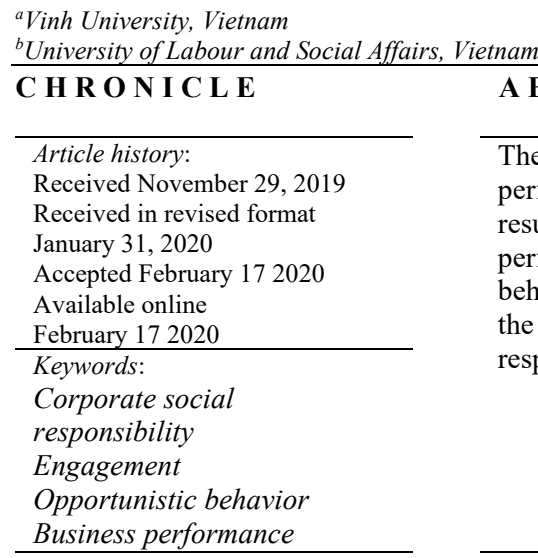

\section{A B S T R A C T}

The study aims to test the impact of social responsibility toward employees on the business performance. The sample selected includes 667 employees in the enterprises. The research results show that the social responsibility factor had direct and indirect impacts on the business performance of enterprises through two intermediaries: cohesion and opportunistic workers' behavior. Based on the research results, we propose a number of recommendations to increase the efficiency of business operations of the enterprises through improving corporate social responsibility toward employees in countries with emerging economies, including Vietnam.

\section{Introduction}

Corporate social responsibility toward employees is attached to the employee's work-related requirements and the organization's ability to meet those requirements. Employees will most likely feel satisfied and motivated to work if they feel that their expectations and organizational commitment to workers are met. According to Hopkins (2003), one of the most obvious intangible benefits of engaging in corporate social responsibility is increased employee loyalty and satisfaction. Mittal et al. (2008) suggest that corporate social responsibility has a positive impact on employee productivity. Employees feel more satisfied with the organization's value values. According to Jenkins (2006), Zairi and Peters (2002), research on corporate social responsibility will often be related to long-term benefits, not short-term benefits. Corporate social responsibility can also attract better employees (Turban \& Greening, 1997). Backhaus et al. (2002) demonstrate that corporate social responsibility increases the attractiveness of a company to potential employees and the most influential areas of corporate social responsibility include environmental issues, community relations and diverse policies. Buzzell and Gale (1987) argue that performance is the degree to which an enterprise's business goals are achieved, related to revenue growth, sales, profits, growth, market share, as well as the level of strategic goal completion. In this same view, Keegan et al. (1989) put forward a matrix of measurement of business results by classifying measurement results based on cost and non-cost. Improving business performance is considered as the key goal for enterprises operating in the market. Katou and Budhwar (2010) point out that performance is positively correlated with the reward direction, compensation based on performance, professional training and development for employees, assessing performance results fairly, and motivating employees to work. According to research by Koh and Boo (2001), corporate social responsibility performance has positive relationship with employee satisfaction and at the same time help employees engaged and motivated to stay longer with

* Corresponding author

E-mail address: taiketoanquocte@gmail.com (D.T. Do)

(C) 2020 by the authors; licensee Growing Science. doi: $10.5267 /$ j.uscm.2020.2.004 
company. Bakiev (2013) argues that high performance through intermediaries such as relationships between employee trust, engagement, and organizational performance awareness have a positive impact on business performance. After studying the relationship between remuneration, performance evaluation, promotion practices and organizational performance, the results of Shahzad et al. (2008) showed that these factors are positively correlated with each other. Up to now, in many of their research projects, many authors have mentioned the relationship between corporate social responsibility toward employees on business performance. Most studies favor the thesis that corporate social responsibility has a positive effect on business performance. Siddiq and Javed (2014), and Adamu Yusoff (2016) suggested that social responsibility of enterprises have a positive and strong impact on business performance. Meanwhile, Khan et al. (2016) also mentioned corporate social responsibility as a good measure to increase the efficiency of business operations of enterprises. Kiran et al. (2015) demonstrate that social responsibility has a positive impact on net profit and net profit margin, total assets of the company but has no significant impact on the profitability of the business. However, in the studies of Rahman et al. (2014), Ofori et al. (2014), there is no relationship between corporate social responsibility and business performance.

In fact, the issue of social responsibility toward employees has been paid much attention and awareness by many businesses through many activities to improve the life quality of employees and their families. Enterprises which implement social responsibility have shown that their benefits not only do not diminish, but increase significantly. Workers have a good spirit, a positive working attitude, cohesion and dedication in their work are promoted. However, most Vietnamese enterprises with small and medium scale still have short-term thinking, fragmented and small working ways. With the aim of getting immediate profits, these businesses have not really taken effective measures to care for employees or ignore the interests of employees. Many businesses are tending to avoid the implementation of social responsibility for employees, which seriously impact on individual benefits of workers, working attitudes, efforts at work as well as labor productivity. As a consequence, this issue reduces the momentum of growth and long-term development of the business.

In this study, we mentioned the impact of corporate social responsibility toward employees on business performance in Vietnamese enterprises. At the same time, this study clarifies the intermediary role of engagement and opportunistic behavior factors in the direct and indirect impact relationships of social responsibility and business performance of enterprises.

\section{Theoretical framework and Hypotheses}

\subsection{Corporate social responsibility toward employees and business performance}

Maignan and Ferrell (2004) argue that a business is socially responsible for its decisions and activities to create and balance the various interests of individuals and organizations involved. Corporate social responsibility toward employees is tied to the employee's work-related requirements and the organization's ability to meet those requirements. Employees will most likely feel satisfied and motivated to work if they feel their expectations and organizational commitment to workers are met at a reasonable level. In addition, Carroll (1979) defines that corporate social responsibility includes society's expectations of the economy, law, ethics and philanthropy of organizations at a given time. Brammer et al. (2007) proposed components of corporate social responsibility including: social responsibility toward society, social responsibility toward the natural environment, social responsibility toward customers, social responsibility toward other external parties, social responsibility toward the law, social responsibility for fairness in policies, social responsibility for training staff. The research results show a correlation between the components of corporate social responsibility and employee engagement with the organization. The following component is the external social responsibility of the corporations and the final part is the issue of training staff. Imran Ali et al. (2010) considered the impact of corporate social responsibility on employee engagement with the organization, as well as how corporate social responsibility and employee engagement affect organizational performance. The study demonstrates that corporate social responsibility including activities for the benefit of employees and their families increases employee engagement with the organization. The more businesses contribute to society, the more they attract potential employees and the more they improve their current level of engagement. Company's positive actions motivate employees to introduce the company to others, making them feel more proud of their company and thus improving their productivity. Moreover, social responsibility also creates credibility for the business with customers, investors, suppliers and governments, followed by the positive effects on decision making that are beneficial to the business. Social responsibility also brings a competitive advantage, thereby positively affecting the effectiveness of the organization. In addition, organizations can enhance employee engagement by promoting socially beneficial activities. All these activities will affect employee engagement with the organization, thereby, affecting employee productivity and thereby increasing the efficiency of the organization. Neely et al. (1995) suggest that business performance is a set of criteria to quantify the efficiency and effectiveness of all aspects of business activities. It is tested by 03 levels: individual, business goals and the relationship between those evaluation criteria and the operating environment (culture, customer satisfaction, development strategy, etc.). Maisel (2001) assesses business performance of enterprises as a system that helps businesses build plans, measure and control the results of sales, marketing, information technology and decision making. business planning and other activities of the enterprise to set goals and create value for people with related interests. According to Kaplan and Norton (1993), the effectiveness of a business is determined from four basic component groups, including finance, customers, internal processes and development learning. It builds the basis for turning business strategy content into execution terms. In addition to the two direct impact factors mentioned in the research content are corporate social responsibility toward employees and business performance. The study also addresses intermediary factors including the 
cohesion and opportunistic behavior of employees in the organization.

According to Meyer and Allen (1997), organizational attachment is a psychological state that indicates the employee's relationship with the organization, demonstrating an inextricable commitment to the organization and a desire to contribute to the accomplishment of the organization's goals. Si and Li (2012) think that organizational engagement is mediated in the relationship between human resource management practices and employee behavior. Cohesion with the organization has the important role in regulating and creating relationships within the organization. At the same time, it creates more support in the work process of workers from colleagues, managers and organizations. According to O'Reilly and Chatman (1986), cohesion with an organization is defined as the psychological state of a member of an organization, reflecting the extent to which individuals absorb or accept the characteristics of the organization. Mowday et al. (1982) refer to organizational commitment as a relative strength of the uniformity of staff and organization and the active involvement of employees in an organization. Meanwhile, Charles and Jennifer (1986) have shown that engagement is the attitude of workers. The authors found that access to engagement in the organization was divided into three factors: compliance, identification, and acquisition. In particular, compliance occurs when attitudes and behaviors are accepted not by shared beliefs but simply by achieving a specific reward. Identity occurs when an individual feels proud to be a member of an organization, respecting the organization's values and achievements without considering it as a personal achievement. Meyer and Allen (1991) proposed three components of engagement: (1) Affective cohesion (Affective): is the emotion of attachment, unity and commitment in the organization. In other words, it is desirable to be an organization member. This is the highest degree of personal attachment to the organization when the individual feels an integral part of the organization and the goals and interests of the organization are placed above the individual goals. (2) Cohesion to maintain (Continuance): is the willingness to work hard, employees realize that they will lose costs when leaving the organization. Therefore, once getting higher benefits from other corporations, workers will leave the organization. (3) Ethical commitment (Normative): as an obligation, employees feel obligated to continue their work. This is the most lax level of cohesion, when the obligations are over, workers will leave the organization. Knowing the above components, businesses should try to create emotional cohesion in their employees, thus ensuring long-term employee retention. Mathieu and Zajac (1990) suggest that the premise for employees to engage with the organization is often classified into personal characteristics, work, work experience and organizational characteristics. Personal characteristics refer to gender, age, education, marital status, job level, and seniority. Job characteristics focus on diversity in job skills, autonomy in tasks, job challenges and scope of work. The characteristics of an organization include its organizational policies, support, information and exchange and recognition. Opportunistic behavior is one that seeks personal gain through fraud (Williamson 1975), which essentially breaks commitments, violates obligations and responsibilities that must be fulfilled (Morgan \& Hunt, 1994). In organizations, the types of behaviors that determine workers' performance include those that are directly related to productivity, absenteeism, and manpower change. The attitude of employees is related to the level of job satisfaction. Satisfaction is related to labor productivity, inversely proportional to the absence of workers. Creating and improving job satisfaction is also the responsibility of managers to employees. Employees' behaviors and attitudes are related to the jobs they undertake.

Opportunistic behavior is considered a form of negative behavior of employees in the organization, dominated and decided by the awareness, attitudes and capabilities of the employees themselves. The person as a member of an organization is influenced by organizational factors such as culture, leadership, power, organizational structure, and groups of organizations in which the employee is a team member.

\subsection{Hypotheses}

Corporate social responsibility toward employees and employee engagement

The study of Nejati and Ghasemi (2013) based on Turker (2008) confirms that corporate social responsibility toward employees has a positive impact on employee engagement with the organization. Research results of Maignan et al. (1999) indicate that social responsibility plays an important role in improving employee engagement. Turker (2008) in his study demonstrated that corporate social responsibility for employees has a great influence on employee engagement. In general, previous studies on the impact of corporate social responsibility toward employees on employee engagement with the organization can be classified into two categories. The first type, the authors analyze how corporate social performance affects potential employees (Albinger and Freeman, 2000; Backhaus et al., 2002; Turban and Greening, 1997, etc.). These studies support the notion that corporate social responsibility toward employees creates the company's reputation and promotes its attractiveness. Second, the authors focus on the impact of the organization's social activities on current employees (Peterson, 2004; Rupp et al., 2007; Wood and Jones, 1995,etc.). Riordan et al. (1997) argued that corporate social responsibility toward employees affects employees' attitudes, attitudes, behaviors and cohesion. Brammer et al. (2007) studied and provided results of the inpact of social responsibility activities on organizational cohesion. Hence, most of the studies agreed and pointed out the direct and positive impact of corporate social responsibility toward employees on employee engagement in the organization. In the context of Vietnamese businesses, in order to test this relationship more accurately, we hypothesized:

$\mathbf{H}_{1}$ : Corporate social responsibility toward employees has a positive impact on employee engagement at Vietnamese businesses. 
Gond et al. (2010) clarified the impact of the implementation of social responsibility toward employees' behaviors and attitudes. Viswesvaran et al. (1998) analyze the association between corporate social responsibility toward employees and employee's opposing behavior. In the organization, there are always fraudulent acts, as well as taking advantage of important relationships and important positions to benefit themselves. This seriously influences the management activities as well as overall business performance. Fulfilling the corporate social responsibility toward employees has an effect on the employees' positive behaviors in building positive relationships with colleagues, limiting negative behaviors and attitudes in work. In the context of Vietnamese businesses, how does the corporate social responsibility issue toward employees affect the opportunistic behavior of individuals in the enterprise? Accordingly, the following hypothesis is established in this study:

$\mathbf{H}_{2}$ : Corporate social responsibility toward employees has a negative impact on opportunity behavior in Vietnamese businesses.

\section{Engagement and opportunistic behavior of employees}

In Theoretical Framework for Relationship Marketing, Morgan and Hunt (1994) have shown that there is a negative relationship between opportunistic behavior and trust, which is the premise of the partner's commitment to a long-term relationship. From an individual level in the enterprise, the research of Ritzer and Trice (1969) proved a positive relationship between employee engagement and compensation policy. Improving employee engagement with the organization also means the process of creating a stable mentality, long-term commitment and limiting negative factors, individual opportunity behaviors in the organization. In order to clarify the relationship between the impact of corporate engagement on the opportunistic behaviors of workers, the hypothesis is formulated:

$\mathbf{H}_{3}$ : Employee engagement has a negative impact on the opportunistic behavior of workers in Vietnamese businesses.

Corporate social responsibility toward employees and business performance

Research by Thorne et al. (1993) has demonstrated that, if an enterprise does not fulfill its social responsibility, its performance will be significantly reduced. Corporation's social responsibility practices increase the willingness of existing employees to improve financial results (Davis, 1973; McGuire et al., 1988). Implementation of social responsibility will have a positive impact on the willingness of workers to participate in production and business activities, increasing productivity and business efficiency for businesses.

In addition, many other studies also show similar results when evaluating corporate social responsibility toward employees has a positive effect on business performance like Siddiq and Javed. (2014), Babola (2012), Khan et al (2016), Akanbi and Ofoegbu (2012), Ahamed et al (2014), Yusoff and Adamu (2016). In order to test the impact of corporate social responsibility towards employees on business performance, in the context of Vietnamese businesses, this study establishes the following hypothesis:

$\mathbf{H}_{4}$ : Corporate social responsibility toward employees has a positive impact on the business performance of Vietnamese businesses.

\section{Employee engagement and business performance}

A number of studies by the authors pointed out that employee engagement impacts organizational processes and performance (Mowday et al., 1982; Allen \& Meyer, 1990; Shaw et al., 2003). Imran Ali et al. (2010) demonstrated that employee engagement has a positive impact on organizational performance. In addition, studies of Bakiev (2013) and Mansour et al. (2014) also show a positive relationship between employee engagement and business performance of enterprises. Employee engagement is an important factor that contributes to the long-term success of the organization. To increase business efficiency, Vietnamese businesses always focus on the cohesion, sustainable relationship between colleagues and the management levels in the business. To test the relationship between these two factors, we suggest the following hypothesis:

H5: The employees engagement has a positive impact on the business performance of Vietnamese businesses.

\section{Opportunistic behavior and business performance}

Studies have shown an indirect effect of opportunistic behavior on firm's business performance. According to Katsikeas et al. (2009), there is a negative impact relationship of opportunistic behavior on trust, thereby affecting businesses performance. Opportunistic behavior often stems from the demand and interests of individuals. In this relationship, the need determines the benefits. Therefore, it is the basis of benefits, and the benefits are the opposite, derived from the demand, based on the demand, which is the expression of the demand. However, if the business performance of the enterprise is heavily influenced by personal interests, it will have a negative effect. Hence, in the context of Vietnamese enterprises, whether there is a direct impact relationship between the opportunistic behavior of employees on the business performance or not. This is the gap the study wants to make clear. The aim of the study is to clarify this research gap. Therefore, this 
study establishes the following hypothesis:

H6: Opportunistic behavior has a negative impact on the business performance of Vietnamese businesses.

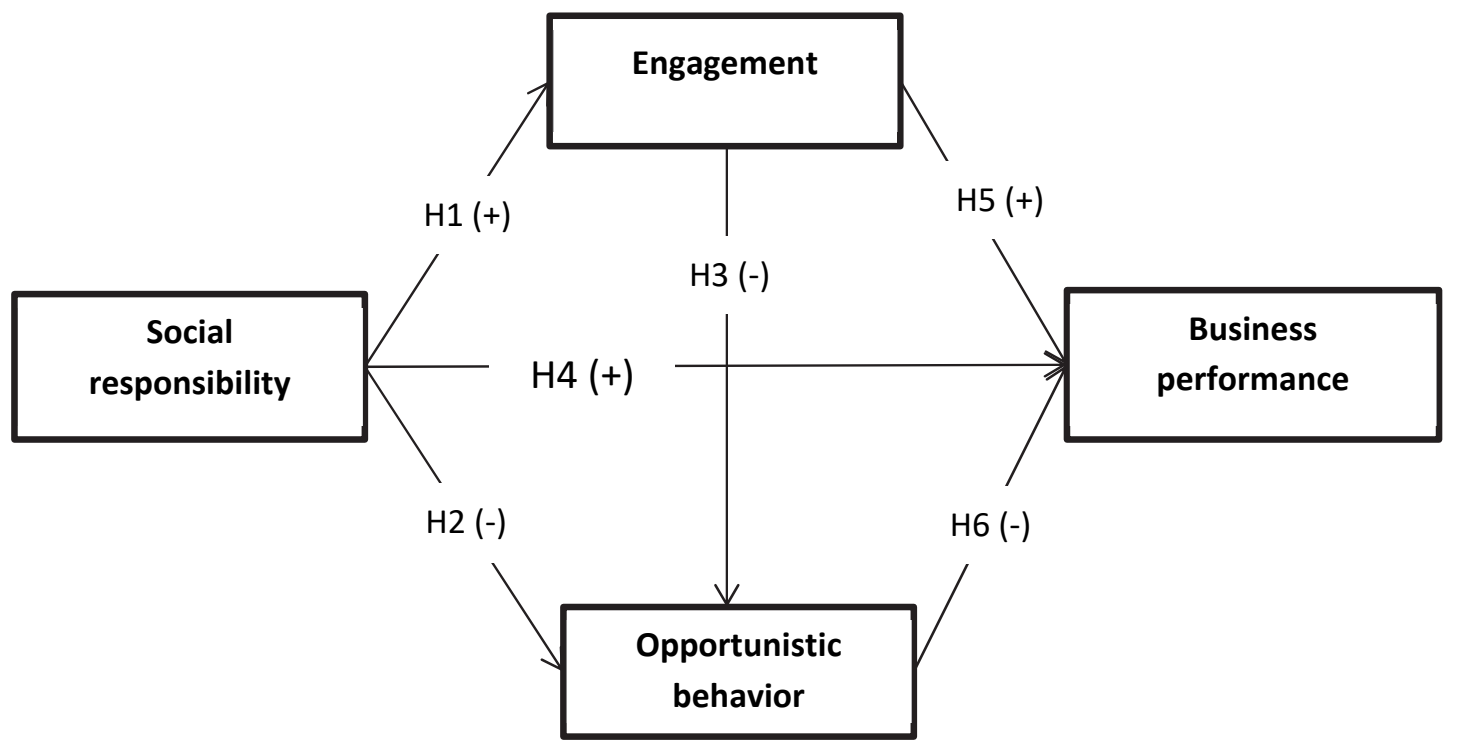

\section{Research methodology}

Fig. 1. Research model

\subsection{Measurement Scales}

Based on the theoretical overview and related research works, the paper proposes a research model with independent and intermediate variables including: corporate social responsibility toward employees, engagement, opportunistic behavior and the target variable that is business performance. The scale used in the research is a Likert scale with 5 levels (Strongly agree; Agree; Normal; Disagree; Strongly disagree). The indicators measuring the applied variables are adjusted in accordance with the characteristics of the sample from the previous studies. "Social responsibility" variable which uses scales by Hopkins (2003) and Clarkson (1995) includes 5 observations. "Engagement" using Meyer's et al. (1993) consists of 5 observations. "Opportunity behavior" using a scale of Katsikeas et al (2009) including 5 observations. Business performance using a Huselid scale (1995) consists of 6 observations.

Table 1

List of variables and indicators

\begin{tabular}{|c|c|c|c|}
\hline Variable & Code & Indicator & Sources \\
\hline \multirow{5}{*}{$\begin{array}{l}\text { Corporate social } \\
\text { responsibility } \\
\text { toward employees }\end{array}$} & TNCX1 & $\begin{array}{l}\text { Encouraging workers to develop skills and long-term careers through assessment } \\
\text { and training }\end{array}$ & \multirow{5}{*}{$\begin{array}{l}\text { Modified application of the } \\
\text { scale of Hopkins (2003) and } \\
\text { Clarkson (1995) }\end{array}$} \\
\hline & TNCX2 & Anti-discrimination in recruitment, training, promotions, salaries and bonuses & \\
\hline & TNCX3 & $\begin{array}{l}\text { Creating a safe working environment and health care for employees (preventing } \\
\text { labor accidents, clean toilets, insurance, etc.) }\end{array}$ & \\
\hline & TNCX4 & $\begin{array}{l}\text { Salary of enterprises compared to the average salary of the economic sector in } \\
\text { which businesses participate }\end{array}$ & \\
\hline & TNCX5 & Interest in spiritual living conditions for employees (sports, arts, tourism) & \\
\hline \multirow[t]{5}{*}{ Engagement } & GK1 & This company has an importan significance for me & \multirow{5}{*}{$\begin{array}{l}\text { Modified application of the } \\
\text { scale of Meyer et al. (1993) }\end{array}$} \\
\hline & GK2 & I am proud to tell my friends about my workplace & \\
\hline & GK3 & I feel the obstacles of the business as my obstacles & \\
\hline & GK4 & I'm glad to choose to work for this business & \\
\hline & GK5 & For me, this is a great place to work & \\
\hline \multirow[t]{5}{*}{$\begin{array}{l}\text { Opportunistic } \\
\text { behavior }\end{array}$} & $\mathrm{CH} 1$ & $\begin{array}{l}\text { In my company, managers often pursue their own interests in the working } \\
\text { process. }\end{array}$ & \multirow{5}{*}{$\begin{array}{l}\text { Modified application of the } \\
\text { scale of Katsikeas et al. } \\
(2009)\end{array}$} \\
\hline & $\mathrm{CH} 2$ & My relationship with colleagues is always dominated by private interests. & \\
\hline & $\mathrm{CH} 3$ & $\begin{array}{l}\text { There are always personal opportunities behaviors in the working process within } \\
\text { the company. }\end{array}$ & \\
\hline & $\mathrm{CH} 4$ & I always had high expectations for job advancement. & \\
\hline & $\mathrm{CH} 5$ & $\begin{array}{l}\text { The results of my work are always heavily influenced by personal goals inside } \\
\text { and outside of the job. }\end{array}$ & \\
\hline \multirow[t]{6}{*}{$\begin{array}{l}\text { Business } \\
\text { performance }\end{array}$} & HQ1 & $\begin{array}{l}\text { Recognizing that the quality of products and services of the company is } \\
\text { guaranteed. }\end{array}$ & \multirow[t]{6}{*}{$\begin{array}{l}\text { Modified application of the } \\
\text { scale of Huselid (1995) }\end{array}$} \\
\hline & HQ2 & Recognizing that that the company has developed new products and services. & \\
\hline & HQ3 & Recognizing that the number of business products of the company has increased. & \\
\hline & HQ4 & Noticing the positive feedback from customers. & \\
\hline & HQ5 & Recognizing that sales of enterprises has increased. & \\
\hline & HQ6 & Recognizing that profitability of enterprises has increased. & \\
\hline
\end{tabular}




\subsection{Data Collection and Sampling}

The sample selected by the non-probability sampling method is a convenient sampling, relatively stratified by provinces and localities in Vietnam. The unit of analysis in this study is workers in enterprises in Vietnam. The sample size for collection is 667 samples. The data collection process is conducted in two ways: direct and online questionnaires distribution. The number of online questionnaires collected was 416, the number of available questionnaires was 358 . In terms of direct survey, the number of questionnaires issued is 650 , the number of questionnaires collected is 472 , the number of questionnaires used is 309 . The total number of valid questionnaires used for analysis is 667 . Based on the study of Hair et al. (1998) for reference to the expected sample size, the minimum sample size is 5 times the total number of observed variables. With the number of observations in the paper is 21 , the research scale includes 667 samples to ensure analysis requirements. The time to complete data collection is from August 2019 to December 2019.

\subsection{Data analysis method}

This study employs applies quantitative methods. The data after collection and cleaning are processed through SPSS and Amos. First, the study assesses the reliability of the scale with Cronbach's Alpha value $>0.7$. Next, the study analyses EFA discovery factor with the aim of determining "convergent values" and "discriminant values of the scale". Then, using AMOS to assess the suitability of the research model through CFA test and finally the research conducts to test the research hypotheses by analyzing SEM model.

\section{Results and discussion}

Verify the reliability of the scale

Cronbach's Alpha test analysis results show that the reliability of the scale used in the analysis that Cronbach's Alpha coefficient of all variables $>0.7$. However, HQ6 indicator has Cronbach's Alpha if Item Delete coefficient as 0.933 which is larger than the Cronbach's Alpha coefficient of HQ variable (0.847). Therefore, in order to increase the suitability of the scale, the study conducts this indicator.

Table 2

Assess the reliability of the scale through Cronbach's Alpha coefficient

\begin{tabular}{llll}
\hline Order & \multicolumn{1}{c}{ Variable } & Code & Cronbach's Alpha coefficient \\
\hline 1 & $\begin{array}{l}\text { Corporate social responsibility towards } \\
\text { employees }\end{array}$ & TNXH & 0.891 \\
2 & Engagement & GK & 0.836 \\
3 & Opportunistic behavior & CH & 0.811 \\
4 & Business performance & HQ & 0.933 \\
\hline
\end{tabular}

\section{EFA analysis}

After conducting the test of the suitability of the scale, the research conducts the analysis of EFA discovery factor. The analysis process is conducted for both independent variables and dependent variables. The analysis results show that the data are eligible for analysis due to the load factor coefficient $>0.5$ and satisfy the two conditions of "Convergence value" (observation variables converge on the same factor) and "Distinctive value" (observed variables that belong to one factor are distinguished from another).

Table 3

\begin{tabular}{llllll}
\multicolumn{2}{l}{ Results of analysis EFA factor } & & & & \\
\hline EFA analysis & $\begin{array}{l}\text { KMO } \\
\text { coefficient }\end{array}$ & P-value & $\begin{array}{l}\text { Variance } \\
\text { extracted }\end{array}$ & $\begin{array}{l}\text { Load factor } \\
\text { coefficient }\end{array}$ \\
\hline Independent variables & 0.864 & 0.000 & 63.522 & All coefficient $>0.5$ & Ensure analysis requirements \\
Target variables (HQ) & 0.852 & 0.000 & 79.248 & All coefficient $>0.5$ & Ensure analysis requirements \\
\hline
\end{tabular}

\section{CFA analysis}

The research results indicate the appropriateness of the measurement model. Chi-square $=706.394, \mathrm{df}=164$, Chi-square/df $=4.307(<5), \mathrm{P}=0.000, \mathrm{GFI}=0.904(>0.9), \mathrm{TLI}=0.920(>0.9), \mathrm{CFI}=0.931(>0.9), \mathrm{RMSEA}=0.070(<0.08)$.

\section{SEM linear structure model analysis}

Conducting analysis of SEM model for the research model, we found that the general indicators are satisfactory. In particular, Chi-square $=706.394, \mathrm{df}=164, \mathrm{Chi}-\mathrm{square} / \mathrm{df}=4.307(<5), \mathrm{P}=0.000, \mathrm{GFI}=0.904(>0.9), \mathrm{TLI}=0.920(>0.9)$, $\mathrm{CFI}=0.931(>0.9), \mathrm{RMSEA}=0.070(<0.08)$. 


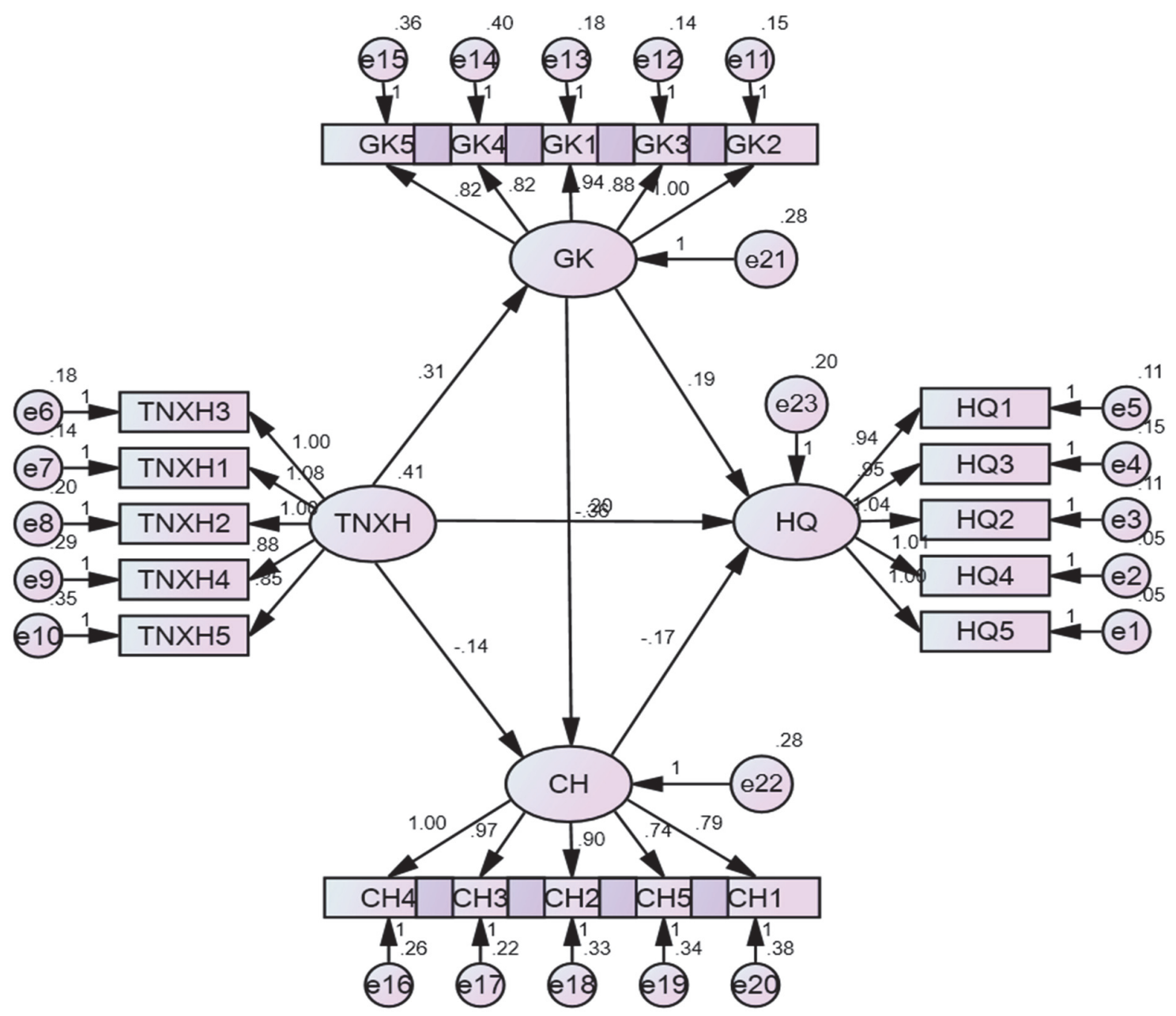

Fig. 2. SEM model analysis

The results of estimating the relationships in the model show that the research model is suitable. With significant levels $\mathrm{P}$ $<0.05$ and regression weights $>0$. All hypotheses are accepted, corresponding to the results of related studies such as Nejati and Ghasemi (2013), Maignan et al. (1999), Turker (2008), Albinger and Freeman (2000), Backhaus et al. (2002), Green, Turban and Greening (1997), Brammer et al. (2007), Gond et al. 2010), Morgan and Hunt (1994), etc. With the hypotheses H4, H5, H6 testing the direct impact of corporate social responsibility factors on employees, engagement and opportunistic behavior at work on business performance in enterprises in Vietnam, the results show that the hypotheses are accepted with significant level $\mathrm{P}<0.05$. In particular, with regression weight $>0$, the corporate social responsibility factor towards employees and the engagement tested have a positive effect on the business performance. This result corresponds to works such as Thorne et al. (1993), Davis (1973), McGuire et al. (1988), Mowday et al. (1982), Allen and Meyer (1991), Herscovitch and Meyer ( 2002), Katsikeas et al. (2009), etc. At the same time, the order of influence is determined by the regression weights of social responsibility (0.203) and employee engagement (0.194).

Table 4

SEM analysis results for the relationships in the model

\begin{tabular}{lllllll}
\hline Hypothesis & Relationship & Mean & S.E. & C.R. & P & Conclusion \\
\hline $\mathrm{H}_{1}$ & $\mathrm{GK} \leftarrow \mathrm{TNXH}$ & 0.313 & 0.038 & 8.247 & 0.000 & Accepted \\
$\mathrm{H}_{2}$ & $\mathrm{CH} \leftarrow \mathrm{TNXH}$ & -0.137 & 0.042 & -3.283 & 0.001 & Accepted \\
$\mathrm{H}_{3}$ & $\mathrm{CH} \leftarrow \mathrm{GK}$ & -0.363 & 0.051 & -7.166 & 0.000 & Accepted \\
$\mathrm{H}_{4}$ & $\mathrm{HQ} \leftarrow \mathrm{TNXH}$ & 0.203 & 0.033 & 6.105 & 0.000 & Accepted \\
$\mathrm{H}_{5}$ & $\mathrm{HQ} \leftarrow \mathrm{GK}$ & 0.194 & 0.041 & 4.698 & 0.000 & Accepted \\
$\mathrm{H}_{6}$ & $\mathrm{HQ} \leftarrow \mathrm{CH}$ & -0.169 & 0.039 & -4.290 & 0.000 & Accepted \\
\hline
\end{tabular}

In addition, the research results also show that, with the regression weight of $-0.169(<0)$ and the significance level $\mathrm{P}<0.05$, it is possible to conclude that the opportunity behavior of employees has a direct and negative impact on business 
performance of corporations in Vietnam. Therefore, if there are more negative opportunistic behaviors, they will affect the productivity of both individuals and organizations, leading to reduction in business performance. At the same time this has a negative impact on the psychology of other employees in the organization. This poses a demand for businesses to pay more attention to the opportunistic behaviors of individuals in the organization, to limit negative behaviors and individualism without the benefit of collectives.

\section{Descriptive statistical analysis}

It can be noticed that the importance of the factors of social responsibility, engagement and opportunistic behavior for business performance. In addition, the determination of the average value also shows the reality of each factor in this study to the business performance of enterprises. With the highest average value of the variables included in the model as 3.9106 , it can be seen that the average business performance of Vietnamese enterprises is quite high. However, if compared with the overall business performance of countries in the region and the world in terms of both the size and the growth rate, this index is still relatively low. Corporate social responsibility toward employees is also a factor that Vietnamese businesses should to pay more attention and focus. The mean value of this factor according to the evaluation level of the study is 3.6573. This index is not really as expected and need to have more improved policies in the near future for businesses. Besides, the mean value of opportunistic behavior is 2.2117. Although compared to other factors in the model, this is the lowest rated, reflecting the positive side in business management activities. However, this is still a relatively high number compared to a factor reflecting the downside of management activity. Businesses should pay more attention to the opportunistic behaviors of individuals in the organization. It is important to develop specific targets for managers and employees in each unit. Moreover, businesses should encourage employees to enhance their work by fairly evaluating policies and recording achievements and creating reasonable incentives. Strengthen control activities in the enterprise is considered as an ideal way to limit self-reliance and psychological dependence on work.

Table 5

The results of the descriptive statistical analysis of the variables' value

\begin{tabular}{llllll}
\hline Variable & $\mathrm{N}$ & Minimum & Maximum & Mean & Std. Deviation \\
\hline HQ & 667 & 1.00 & 5.00 & 3.9106 & 0.52852 \\
TNXH & 667 & 1.00 & 5.00 & 3.6573 & 0.65642 \\
GK & 667 & 1.00 & 5.00 & 3.7247 & 0.55098 \\
CH & 667 & 1.00 & 4.80 & 2.2117 & 0.57269 \\
\hline
\end{tabular}

\section{Conclusions and implications}

This study has examined the impact of corporate social responsibility toward employees on business performance of enterprises through two intermediaries: engagement and opportunistic behavior in the context of Vietnamese enterprises. The research results have indicated that the social responsibility factor had a direct and indirect effect on the business performance through two intermediaries: engagement and opportunistic behavior of employees. In particular, corporate social responsibility toward employees and engagement are tested to have a positive impact on the business performance of enterprises with the order of influence identified as social responsibility, employee engagement. At the same time, the study has also pointed out the negative impact of opportunistic behavior factor on the business performance of Vietnamese enterprises. Based on the research results, we propose some following suggestions as below:

Firstly, in terms of corporate social responsibility toward employees, enterprises should encourage employees to develop skills and long-term career through reasonable job evaluation activities, creating opportunities for employees to be trained and develop occupational skills. Besides, discrimination in all management activities and labor policies should be avoided from recruitment, labor relations, allowances, etc. It is significantly important to create a safe working environment and health and spiritual care for workers.

Secondly, in terms of engagement, paying attention to the demand of the mid-level executive's job is considered of vital importance for leaders to improve business performance. In addition to meeting the physical needs, businesses need to focus on developing the skills of each individual, recognizing the manager's performance appropriately and listening to their feedback and even employees under management to have timely encouragement policies. It is necessary to create a dynamic working environment, foster relationships between colleagues in the organization, create a professional working culture, build a friendly atmosphere, enhance support and coordination in work between individuals and divisions within the organization so that middle managers can maximize their capabilities in the job.

Last but not least, in terms of opportunistic behavior of individuals in the organization, it is important to develop specific targets for managers and employees in each unit. Businesses should encourage employees to enhance their work by fairly evaluating policies and recording achievements and creating reasonable incentives. Strengthen control activities in the enterprise is considered as an ideal way to limit self-reliance and psychological dependence on work. 


\section{References}

Ahamed, W.S.W., Almsafir, M.K., \& Al-Smadi, A.W. (2014). Does corporate social responsibility lead to improve in firm financial performance evidence from Malaysia. International Journal of Economics and Finance, 6(3), 126-138.

Akanbi, P.A., \& Ofoegbu, O.E. (2012). Impact of corporate social responsibility on bank performance in Nigeria. Journal of Us- China Public Administration, 9(4), 374-383.

Albinger, H.S., \& Freeman, S.J. (2000). Corporate social performance and attractiveness as an employer to different job seeking populations. Journal of Business Ethics, 28(3), 243-253.

Allen, N.J., \& Meyer, J.P. (1990). The measurement and antecedents of affective, continuance and normative commitment to the organization. Journal of Occupational Psychology, 63(1), 1-18.

Babola, Y.A. (2012). The impact of corporate social responsibility on firm's profitability in Nigeria. European Journal of Economies, Finance and Administrative Science, 45, 39-49.

Backhaus, K., Stone, B., \& Heiner, K. (2002). Exploring the relationship between corporate social performance and employer attractiveness. Business \& Society, 41(3), 292-318

Bakiev, E. (2013). The influence of interpersonal trust and organizational commitment on perceived organizational performance. Journal of Applied Economics and Business Research, 3(3), 166-180.

Brammer, S., Millington, A., \& Rayton, B. (2007). The contribution of corporate social responsibility to organizational commitment. The International Journal of Human Resource Management, 18(10), 1701-1719.

Buzzell, R.D., \& Gale, B.T. (1987), The PIMS Principles: Linking Strategy to Performance, Simon and Schuster.

Carroll, A.B. (1979). A Three-Dimensional Conceptual Model of Social Performance. The Academy of Management Review, 4(4), 497-505.

Charles, O.R., \& Jennifer, C. (1986), Organizational commitment and psychological attachment: The effects of compliance, identification, and internalization on prosocial behavior. Journal of applied psychology, 71(3), 492-499.

Clarkson, M. (1995). A Stakeholder framework for analysing and evaluating corporate social performance. Academy of Management Review, 20(1), 92-118.

Davis, J.H. (1973). Group decision and social interaction: A theory of social decision schemes. Psychological Review, 80(2), 97-125.

Gond, J., El-Akremi, A., Igalens, J. \& Swaen, V. (2010). Corporate social responsibility influence on employee. ICCSR Research Paper Series, 54.

Hair, J.F., Anderson, R.E., Tatham, R.L. \& Black, W.C. (1998). Multivariate Data Analysis, (5th Edition). Upper Saddle River, NJ: Prentice Hall.

Hopkins, M. (2003). The planetary bargain: Corporate social responsibility. Matters Earthscan Publications Ltd.: London

Huselid, M.A. (1995), The Impact of Human Resource Management Practices On Turnover, Productivity, And Corporate Financial Performance. Academy of Management Journal, 38(3), 635-672.

Imran, Ali, Rehman, K.U., Ali, S.I., Yousaf, J., \& Zia, M. (2010). Corporate social responsibility influences, employee commitment and organizational performance. African journal of Business Management, 4(13), 2796-2801.

Jenkins, H. (2006), Convergence culture: Where old and new media collide. Social Science Computer Review, 26(2), 252254.

Kaplan, R.S., \& Norton, D.P. (1993). Implementing the balanced scorecard at FMC corporation: An interview with Larry D. Brady. Harvard Business Review, 71(5), 143-147.

Katou, A.A., \& Budhwar, P.S. (2010). Causal relationship between HRM policies and organisational performance: Evidence from the Greek manufacturing sector. European Management Journal, 28(1), 25-39.

Katsikeas, C.S., Dionysis, S, \& Daniel, C. (2009). Developing successful trust-Based international exchange relationships. Journal of International Business Studies, 40(1), 132-155.

Keegan, D.P., Eiler, R.G., \& Jones, C.R. (1989). Are your performance measures obsolete?. Management Accounting.

Khan, M., Serafeim, G., \& Yoon, A. (2016). Corporate sustainability: First evidence on materiality. The Accounting Review, 91(6), 1697-1724.

Kiran, S., Kakakhel, J. S., \& Saheen, F. (2015). Corporate social responsibility and firm profitability: A case of oil and gas sector of Pakistan, City University Research Journal, 5(1), 110-119.

Koh, H.C, \& Boo, H.Y. (2001). The link between organizational ethics and job satisfaction: A study of managers in Singapore. Journal of Business Ethics, 29(4), 309-324.

Maignan, I., \& Ferrell, O. (2004). Corporate social responsibility and marketing: An integrative framework. Journal of the Academy of Marketing Science, 32(1), 3-19.

Maignan, I., Ferrell, O. C., \& Hult, G. T. M. (1999). Corporate citizenship: Cultural antecedents and business benefits. Journal of the Academy of Marketing Science, 27(4), 455-469.

Maisel, L. S. (2001). Performance measurement practices survey results, Ewing, NJ: American Institute of Certified Public Accountants.

Mansour, N., Gara, E., \& Gaha, C. (2014). Getting inside the black box: HR practices and firm performance within the Tunisian financial services industry. Personnel Review, 43(4), 490- 514.

Mathieu, J.E. \& Zajac, D.M. (1990). A review and meta-analysis of the antecedents, correlates, and consequences of organizational commitment. Psychological Bulletin, 108(2), 171-194

McGuire, J.B., Sundgren, A., \& Thomas, S. (1988). Corporate social responsibility and firm financial performance. Academy of Management Journal, 31, 854-872. 
Meyer, J.P., Allen, N.J., \& Allen, N.J. (1997). Commitment in the workplace. Sage Publications.

Meyer, J.P., Allen, N.J., \& Smith, C.A. (1993). Commitment to organizations and occupations: Extension and test of a three-component conceptualization. Journal of applied psychology, 78(4), 538.

Meyer, J.P., \& Allen, N.J. (1991). A three-component conceptualization of organizational commitment. Human Resource Management Review, 1(1), 61-89.

Mittal, R., Sinha, N., \& Singh, A. (2008). An analysis of linkage between economic value and corporate. Social Responsibility Management Decision, 46(9), 1437-43.

Morgan, R.M., \& Hunt, S.D. (1994). The Commitment-trust theory of relationship marketing. Journal of Marketing, 58(3), 20-38.

Mowday, R.T., Porter, L.W. \& Steers, R.M. (1982). Employee-Organization Linkages: The Psychology of Commitment. Absenteeism, and Turnover, Academic Press, New York.

Neely, A., Gregory, M., \& Platts, K. (1995). Performance measurement system design: a literature review and research agenda. International Journal of Operations \& Production Management, 15(4), 80-116.

Nejati, M., \& Ghasemi, S. (2013). Corporate social responsibility and organizational commitment: Empirical findings from a developing country. Journal of Global Responsibility, 4(2), 263-275.

Ofori, D.F., Nyuur, R.B., \& S-Darko, M.D. (2014). Corporate social responsibility and financial performance: Fact or fiction?, Acta Commercii, 14(1), 1-11.

O'Reilly, C.A., \& Chatman, J. (1986). Organizational commitment and psychological attachment: The effects of compliance, identification, and internalization on prosocial behavior. Journal of Applied Psychology, 71(3), $492-499$.

Peterson, D.K. (2004). The relationship between perceptions of corporate citizenship and organizational commitment. Business \& Society, 43(3), 296-319.

Rahman, M. M., Rashid, M.M., \& Haque, R.M. (2014). Corporate social responsibility and financial performance: A case study of Jamuna Bank Limited, Bangladesh. Asian Journal of Finance and Accounting, 6(2), 351-361.

Riordan, C.M., Gatewood, R.D., \& Bill, J.B. (1997). Corporate image: Employee reactions and implications for managing corporate social performance. Journal of Business Ethics, 16(4), 401-412.

Ritzer, G., \& Trice, H. (1969). An empirical study of Howard Becker'side-bet theory. Social Forces, 47(6), $475-478$.

Rupp, D.E., Aguilera, R.V., Williams, C.A., \& Ganapathi, J. (2007). Putting the S back in corporate social responsibility: A multilevel theory of social change in organizations. Academy of Management Review, 32(3), 836-863.

Shahzad, K., Bashir, S., \& Ramay, M.I. (2008). Impact of HR practices on perceived performance of university teachers in Pakistan. International Review of Business Research Papers, 4(2), 302-315.

Shaw, J.D., Delery, J.E., \& Abdulla, M.H. (2003). Organizational commitment and performance among guest workers and citizens of an Arab country. Journal of Business Research, 56(12), 1021-1030.

Si, S., \& Li, Y. (2012). Human resource management practices on exit, voice, loyalty, and neglect: Organizational commitment as a mediator. International Journal of Human Resource Management, 23(8), 1705-1716.

Siddiq, S., \& Javed, S. (2014). Impact of CSR on organizational performance. European Journal of Business and Management, 6(27), 40-45.

Thorne, P.D., Hardcastle, P.J. \& Soulsby, R.L. (1993). Analysis of acoustic measurements of suspended sediments. Journal of Geophysical Research, 98(C1), 899-910.

Turban, D.B., \& Greening, D.W. (1997). Corporate social performance and organizational attractiveness to prospective employees. Academy of Management Journal, 40(3), 658-672.

Turker, D. (2008). Measuring corporate social responsibility: A scale development study. Journal of Business Ethics, 85(4), 411-427.

Viswesvaran, C., Deshpande, S.P., \& Joseph, J. (1998). Job satisfaction as a function of top management support for ethical behavior: A study of Indian managers. Journal of Business Ethics, 17(4), 365-371.

Williamson (1975), Markets and Hierarchies. New York: Free Press.

Wood, D.J., \& Jones, R.E. (1995). Stakeholder mismatching: A theoretical problem in empirical research on corporate social performance. The International Journal of Organizational Analysis, 3(3), 229-267.

Yousoff, W.F.W., \& Adamu, M.S. (2016). The relationship between corporate social responsibility and financial performance: Evidence from Malaysia. International Business Management, 10(4), 345-351.

Zairi, M. \& Peters, J. (2002). The impact of social responsibility on business performance. Managerial Auditing Journal, $17(4), 174-178$.

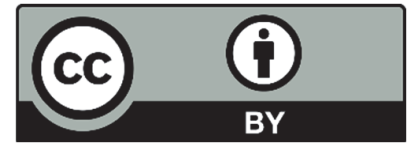

(C) 2020 by the authors; licensee Growing Science, Canada. This is an open access article distributed under the terms and conditions of the Creative Commons Attribution (CC-BY) license (http://creativecommons.org/licenses/by/4.0/). 